\title{
PEMBERDAYAAN IBU RUMAH TANGGA DI KELURAHAN CINERE MEMANFAATKAN SAMPAH ANORGANIK MENJADI BARANG KERAJINAN YANG BERNILAI EKONOMI
}

\author{
Marina Ery Setiyawati ${ }^{1}$, Fathinah Ranggauni Hardy ${ }^{2}$, Putri Permatasari ${ }^{3}$ \\ ${ }^{1}$ Universitas Pembangunan Nasional Veteran Jakarta \\ ${ }^{2}$ Universitas Pembangunan Nasional Veteran Jakarta \\ ${ }^{3}$ Universitas Pembangunan Nasional Veteran Jakarta \\ Coressponding Author: fathinahranggaunihardy@gmail.com
}

\begin{abstract}
ABSTRAK
Sampah rumah tangga khususnya sampah anorganik merupakan masalah tersendiri karena sampah jenis ini sulit didegradasi. Peran serta ibu rumah tangga dalam mengelola sampah rumah tangga, terutama sampah anorganik, akan sangat bermanfaat bagi lingkungan. Permasalahannya adalah bagaimanakah cara mengumpulkan dan mengelola sampah anorganik yang berasal dari aktivitas rumah tangga dan bagaimanakah cara memberikan pengetahuan kepada ibu-ibu rumah tangga untuk meminimalisasi limbah anorganik dengan cara memanfaatkannya menjadi barang-barang kerajinan yang bernilai ekonomi. Metode yang dilakukan adalah dengan mengadakan kegiatan pelatihan dan praktek langsung kepada ibu-ibu rumah tangga di lokasi kegiatan, yaitu di Kelurahan Cinere. Materi pelatihan meliputi seluk-beluk sampah anorganik rumah tangga, serta cara pengelolaan dan pengolahannya menjadi barang kerajinan yang bernilai ekonomi. Jenis sampah yang dimanfaatkan terbatas pada sampah sedotan bekas, karton bekas, dan aneka plastik bekas kemasan. Kegiatan kemitraan masyarakat dilakukan pada Jumat, 14 September 2018 di Kantor Lurah Kel. Cinere Kec. Cinere Kota Depok. Kegiatan dilakukan dengan metode ceramah dan demonstrasi. Metode ceramah untuk menjelaskan tentang pengolahan sampah anorganik yang akan dijadikan kerajinan tangan yang bernilai ekonomi. Hasil kegiatan pelatihan diadakan dapat memberikan bekal keterampilan kepada peserta untuk mengelola sampah anorganik, terutama sampah plastik, menjadi barang-barang kerajinan yang mempunyai nilai jual, seperti produk tas daur ulang dari sampah plastik bekas kemasan.

Kata Kunci : Pemberdayaan, ibu rumah tangga, pengolahan sampah, anorganik.
\end{abstract}

\section{PENDAHULUAN}

Permasalahan lingkungan telah menjadi isu global, setelah hampir semua elemen masyarakat menyadari akan bahaya yang ditimbulkan dari kerusakan lingkungan. Salah satu penyebab kerusakan lingkungan adalah pencemaran lingkungan yang disebabkan oleh menumpuknya limbah yang dihasilkan oleh manusia. Limbah adalah segala sesuatu yang sudah tidak terpakai lagi sebagai barang produksi maupun konsumsi, yang jika langsung dibuang ke lingkungan tanpa pengolahan terlebih dahulu dapat menjadi beban bagi lingkungan.

Bermacam limbah yang dihasilkan oleh aktivitas manusia setiap harinya, ada yang berujud padat, cair maupun gas. Limbah yang berujud padat biasa disebut dengan sampah. Beragam aktivitas manusia dapat menimbulkan sampah, baik aktivitas industri, pertanian, rumah sakit, maupun aktivitas domestik (rumah tangga). Berbagai macam limbah atau sampah tersebut jika hanya langsung dibuang ke lingkungan maka akan menyebabkan pencemaran lingkungan dan kerusakan lingkungan, yang pada akhirnya akan merugikan manusia sendiri.

Dewasa ini telah mulai muncul kesadaran bahwa karena setiap orang berhak atas lingkungan hidup yang layak dan nyaman, maka setiap orang wajib pula menjaga 
kenyamanan lingkungan. Hal itu berarti bahwa setiap orang harus paham tentang lingkungan hidupnya, serta wajib memelihara kelestarian lingkungan tanpa kecuali. Di berbagai kota telah mencanangkan program green and clean, yaitu program yang bertekad mewujudkan kota yang bersih dan nyaman tanpa sampah yang berserakan. Program ini antara lain dengan memanfaatkan peran warga, termasuk ibu-ibu rumah tangga, dalam mengurangi dan memanfaatkan sampah yang ada di sekitarnya.

Ibu rumah tangga merupakan bagian dari masyarakat yang menghasilkan limbah atau sampah. Aktivitas rumah tangga menyumbang sampah yang cukup signifikan ke lingkungan setiap harinya, baik sampah organik maupun sampah anorganik. Penanganan sampah anorganik relatif lebih rumit daripada sampah organik, karena sampah anorganik tidak dapat terurai secara alami. Sampah anorganik yang berasal dari aktivitas rumah tangga bermacam-macam, seperti sampah plastik bekas kemasan suatu produk keperluan rumah tangga, tas kresek, sedotan minuman, kaleng, dll. Sampah anorganik tersebut selama ini kebanyakan hanya dibuang dan menumpuk menjadi sampah.

Adanya kepedulian dari ibu rumah tangga untuk meminimalkan sampah rumah tangga tentunya akan sangat membantu mengurangi timbunan sampah keseluruhan yang masuk ke lingkungan. Meminimalkan sampah ini dapat dilakukan dengan cara 3R, yaitu reuse (pakai ulang), reduce (mengurangi timbulnya sampah), dan recycle (mendaur ulang menjadi barang yang berguna). Pengenalan teknologi sederhana bagi ibu-ibu rumah tangga dalam rangka meminimalisasi limbah rumah tangga, khususnya sampah anorganik, tentunya akan sangat bermanfaat. Sampah anorganik yang berasal dari aktivitas rumah tangga dapat dijadikan barang-barang yang bermanfaat dan bernilai ekonomi, melalui keterampilan khusus, sehingga dapat dijual dan menambah income bagi keluarga.

Kelurahan Cinere merupakan salah satu Kelurahan yang berada di Kota Depok . agar menambah pendapatan Ibu Rumah Tangga didaerah tersebut dapat diberdayakan untuk melakukan aktivitas rumah tangga dapat menjadikan barang-barang yang bermanfaat dan bernilai ekonomi, melalui keterampilan khusus, sehingga dapat dijual dan menambah income bagi keluarga.

Kurangnya pengetahuan dari ibu-ibu rumah tangga di Kelurahan Cinere, sebagai bagian dari masyarakat, tentang lingkungan hidupnya menyebabkan rendahnya kesadaran untuk turut berperan serta dalam kegiatan minimalisasi limbah demi kelestarian lingkungan. Padahal, para ibu rumah tangga merupakan penyumbang limbah domestik dari aktivitas rumah tangga yang cukup signifikan.

Permasalahan yang perlu diatasi adalah bagaimana memberikan pengetahuan, keterampilan dan pengalaman kepada ibu-ibu rumah tangga tersebut untuk mengelola dan mengolah sampah anorganik yang dihasilkannya dengan teknologi yang sederhana menjadi barang kerajinan yang bernilai ekonomi, dan membawa dampak positif terhadap lingkungan. 


\section{METODE KEGIATAN}

Sasaran kegiatan program kemitraan masyarakat ini adalah kaum ibu rumah tangga di PKK Kelurahan Cinere. Dari hasil survai awal, ibu-ibu rumah tangga di lokasi ini sangat mengharapkan pengetahuan dan kerampilan tentang mengolah sampah anorganik menjadi barang kerajinan. Pertimbangan memilih kaum ibu adalah karena ibu berperan penting dalam mengatur jalannya roda rumah tangga atau keluarga dan penyumbang sampah rumah tangga terbesar dalam aktivitas rumah tangganya sehari-hari. Jadi, diharapkan kaum ibu nantinya dapat mengelola dan mengolah sendiri sampah anorganik yang dihasilkannya menjadi barang kerajinan yang bernilai ekonomi, sehingga bisa menambah pendapatan keluarga. Diharapkan nantinya aktivitas mengolah sampah sendiri tersebut dapat menular kepada anggota keluarga yang lain, dan menjadi suatu kebiasaan yang bermanfaat di masyarakat Kelurahan Cinere.

Kegiatan program kemitraan masyarakat ini dilakukan dengan mendatangi lokasi kegiatan, yaitu di PKK Kelurahan Cinere. Ibu-ibu rumah tangga di daerah tersebut diundang untuk berkumpul di salah satu rumah warga, kemudian diberikan materi tentang seluk-beluk limbah rumah tangga dan bahaya yang bisa ditimbulkannya bagi lingkungan, serta upaya mengelola sampah anorganik rumah tangga dengan gerakan 3R. Selanjutnya, diberikan pelatihan/demonstrasi pembuatan barang kerajinan dari sampah anorganik yang dapat bernilai ekonomi. Untuk menambah motivasi ibu-ibu rumah tangga dalam menambah income keluarga dari barang kerajinan hasil daur ulang sampah anorganik tersebut, didatangkan nara sumber yang telah sukses menjalankan program daur ulang sampah anorganik. Satu bulan kemudian diadakan evaluasi keberhasilan kegiatan.

\section{HASIL}

Adapun garis besar hasil pelaksanaan kegiatan adalah sebagai berikut:

1. Langkah awal kegiatan, yaitu penyampaian gagasan pelaksanaan pengabdian kepada Ketua PKK Kelurahan Cinere berjalan lancar. Ibu-ibu rumah tangga dan remaja putri di lokasi pengabdian siap menerima kedatangan tim pengabdian masyarakat dari UPN

2. Hasil pelaksanaan kegiatan pelatihan pengelolaan sampah anorganik menjadi aneka kreasi daur ulang sebagai berikut:

a. Kegiatan pengabdian dilaksanakan pada hari Jumat, tanggal 14 September 2018. Kegiatan pengabdian dihadiri oleh 30 orang peserta (semua peserta yang diundang hadir) dan peserta menunjukkan antusiasme cukup besar terhadap program pengabdian dari tim PKM .

b. Materi pelatihan dapat semuanya disampaikan oleh tim PKM, meskipun tidak disampaikan secara detil.

c. Kemampuan peserta pelatihan dalam penguasaan materi pengelolaan sampah anorganik menjadi aneka kreasi daur ulang cukup baik.

d. Program pengabdian berhasil memberdayakan ibu-ibu rumah tangga dan remaja putri di lokasi pengabdian untuk mengolah sampah anorganik (botol plastik bekas) menjadi aneka kreasi daur ulang (bunga, bros, hiasan tas) dengan 
bantuan alat berupa pisau, gunting, tang, dan aksesoris tambahan lainnya.

\section{PEMBAHASAN}

Pelaksanaan program pengabdian di Kelurahan Cinere, Kota Depok berjalan dengan baik. Program pengabdian berupa pelatihan pengelolaan sampah anorganik menjadi aneka kreasi daur ulang perlu terus diupayakan mengingat produksi sampah rumah tangga semakin banyak dan didukung rendahnya kesadaran 3R, yaitu reuse (memakai kembali barang bekas yang masih bisa dipakai), reduce (berusaha mengurangi sampah), dan recycle (mendaur ulang sampah agar dapat dimanfaatkan). Hal ini menjadi pertimbangan bagi Tim PKM untuk mencari cara yang tepat dalam mengelola sampah anorganik sehingga tidak mencemari lingkungan, tetapi justru mampu memberikan keuntungan bagi masyarakat, yaitu dengan menjadikan sampah anorganik (botol plastik bekas) menjadi berbagai kreasi yang mempunyai nilai ekonomis, seperti bunga, bros, maupun hiasan tas.

Pada tahap awal program pengabdian, peserta pelatihan diberikan pengetahuan tentang sampah, jenis sampah, dan sumber sampah, pengelolaan sampah dan 3R (reduce, reuse, recycle), serta pengelolaan sampah anorganik menjadi aneka kreasi daur ulang. Dalam tahap ini peserta pelatihan diubah pola pikirnya terhadap sampah, "jika dulunya barang bekas langsung kita buang dan menjadi tumpukan sampah", maka pola pikir ini harus kita ubah menjadi "sampah dapat kita olah menjadi sesuatu benda yang berguna". Dengan menerapkan prinsip recycle, barang-barang bekas atau sampah dapat diolah kembali menjadi suatu bentuk yang memiliki daya guna seiring dengan kreatifitas yang dimiliki. Dengan kreatifitas yang dimiliki, botol plastik bekas warna-warni dapat dijadikan berbagai bentuk yang cantik sehingga terlihat artistik dan seperti tidak terbuat dari bahan botol plastik bekas. Dalam berkreasi dengan botol plastik bekas, terlebih dahulu botol kita bersihkan, selanjutnya botol dipotong dengan menggunakan tang/pisau/gunting untuk dibuat berbagai kreasi, seperti bunga, bros, maupun hiasan tas.

Adapun garis besar hasil pelaksanaan kegiatan adalah sebagai berikut:

1. Langkah awal kegiatan, yaitu penyampaian gagasan pelaksanaan pengabdian kepada Ketua PKK Kelurahan Cinere berjalan lancar. Ibu-ibu rumah tangga dan remaja putri di lokasi pengabdian siap menerima kedatangan tim pengabdian masyarakat dari UPN

2. Hasil pelaksanaan kegiatan pelatihan pengelolaan sampah anorganik menjadi aneka kreasi daur ulang sebagai berikut:

a. Kegiatan pengabdian dilaksanakan pada hari Jumat, tanggal 14 September 2018. Kegiatan pengabdian dihadiri oleh 30 orang peserta (semua peserta yang diundang hadir) dan peserta menunjukkan antusiasme cukup besar terhadap program pengabdian dari tim PKM .

b. Materi pelatihan dapat semuanya disampaikan oleh tim PKM, meskipun tidak disampaikan secara detil.

c. Kemampuan peserta pelatihan dalam penguasaan materi pengelolaan sampah anorganik menjadi aneka kreasi daur ulang cukup baik. 
d. Program pengabdian berhasil memberdayakan ibu-ibu rumah tangga dan remaja putri di lokasi pengabdian untuk mengolah sampah anorganik (botol plastik bekas) menjadi aneka kreasi daur ulang (bunga, bros, hiasan tas) dengan bantuan alat berupa pisau, gunting, tang, dan aksesoris tambahan lainnya.

3. Penyusunan laporan akhir hasil pengabdian pengelolaan sampah anorganik menjadi aneka kreasi daur ulang, yang dilakukan secara tertulis kepada LPPM UPN. Sebelum pengumpulan laporan akhir.

Hasil kegiatan PKM secara garis besar dapat dilihat berdasarkan beberapa komponen berikut:

1. Keberhasilan target jumlah peserta pelatihan

Keberhasilan target jumlah peserta pelatihan dapat dikatakan sangat baik. Target jumlah peserta pelatihan sebanyak 30 orang dan dalam pelaksanaan pengabdian dapat hadir sebanyak 30 orang (100\%). Hal ini didukung peran Ibu Ketua PKK mulai dari persiapan, penyebaran undangan, penyediaan tempat dan peralatannya.

2. Ketercapaian tujuan pelatihan

Ketercapaian tujuan pelatihan dapat dikatakan baik (80\%). Kegiatan pengabdian ini berhasil memberdayakan ibu-ibu rumah tangga dan remaja putri di lokasi pengabdian dengan mengolah botol plastik bekas menjadi bunga, bros, maupun hiasan tas.

3. Ketercapaian target materi yang telah direncanakan

Ketercapaian target materi yang telah direncanakan dapat dikatakan baik (80\%). Semua materi pelatihan dapat disampaikan secara keseluruhan meskipun tidak secara detil karena keterbatasan waktu. Materi pelatihan yang telah disampaikan adalah kajian sampah, jenis sampah, dan sumber sampah, pengelolaan sampah dan 3R (reduce, reuse, recycle), serta pengelolaan sampah anorganik menjadi aneka kreasi daur ulang.

4. Kemampuan peserta dalam penguasaan materi

Kemampuan peserta dalam penguasaan materi dapat dikatakan baik (80\%). Hal ini didukung penggunaan metode ceramah dan demonstrasi untuk meningkatkan kemampuan peserta pelatihan dalam menyerap materi yang disampaikan oleh narasumber. Secara keseluruhan kegiatan pelatihan pengelolaan sampah anorganik menjadi aneka kreasi daur ulang dinilai berhasil. Keberhasilan ini selain diukur dari keempat komponen di atas, juga dapat dilihat dari kepuasan peserta setelah mengikuti kegiatan pelatihan. Manfaat yang dapat diperoleh para peserta pelatihan adalah memahami pengelolaan sampah anorganik menjadi aneka kreasi daur ulang sehingga dapat turut serta dalam menjaga kelestarian lingkungan di sekitarnya.

\section{KESIMPULAN}

Berdasarkan uraian dalam pembahasan, maka dapat disimpulkan sebagai berikut:

1. Pelatihan pengelolaan sampah anorganik menjadi aneka kreasi daur ulang di lokasi pengabdian dapat meningkatkan pengetahuan ibu-ibu rumah tangga tentang pengelolaan sampah anorganik menjadi aneka kreasi daur ulang serta memberdayakan mereka dalam pengelolaan sampah anorganik (botol plastik bekas) menjadi aneka 
kreasi daur ulang (bunga, bros, hiasan tas).

2. Peningkatan pengetahuan bagi peserta pelatihan tentang pengelolaan sampah anorganik menjadi aneka kreasi daur ulang dilakukan dengan metode ceramah dan demonstrasi.

\section{SARAN}

1. Kegiatan pengabdian ini diharapkan ke depan dapat sampai membuka akses pasar bagi hasil produksi (aneka kreasi daur ulang).

2. Program pengabdian ini diharapkan dapat dilanjutkan pada tahun-tahun berikutnya di lokasi lain untuk menunjang kelestarian lingkungan, disamping dapat membantu meningkatkan pendapatan keluarga.

\section{DAFTAR PUSTAKA}

Anonim. 1987. Buku Petunjuk Pencegahan dan Penanggulangan Pencemaran Limbah Padat dan Cair Industri. Jakarta: Departemen Perindustrian

Moh. Soerjani, Rofiq Ahmad, dan Rozy Munir. 1987. Lingkungan: Sumberdaya Alam dan Kependudukan dalam Pembangunan. Jakarta: Penerbit UI Press.

Hastuti dan Dyah Respati SS. 2009. Model Pemberdayaan Perempuan Miskin Berbasis Pemanfaatan Sumberdaya Perdesaan Sebagai Upaya Pengentasan Kemiskinan di Perdesaan Lereng Merapi. 